\title{
ABAD FACIOLINCE, FUGUET, VALENCIA Y VOLPI: REDEFINICIÓN DE LA PROSA NO FICTICIA HISPANOAMERICANA
}

\author{
ABAD FACIOLINCE, FUGUET, VALENCIA AND VOLPI: \\ REDEFINITION OF SPANISH AMERICAN NON-FICTION PROSE
}

\section{WILFRIDO H. CORRAL*}

\section{RESUMEN}

Sin límites respecto a medios y la migración de las formas, ha habido un cambio mayor en la recepción de la prosa no ficticia de los autores asociados con la nueva "nueva" narrativa hispanoamericana. Genéricamente, se dan cambios que coinciden con transformaciones paradigmáticas en las disciplinas humanísticas. Si autores anteriores efectuaban permutaciones en el "ensayo", los recientes modifican el estatus cultural de escritos afines, en revistas académicas, crítica, periodismo, entrevistas, y blogs, entre otros. Por medio del análisis de obras representativas de Abad Faciolince, Fuguet, Valencia y Volpi, este artículo examina (con Aira, Bolaño y Agamben en mente) cómo se va redefiniendo esa prosa y cultura.

Palabras clave: Abad Faciolince, Fuguet, Valencia, Volpi, prosa/cultura no ficticia, nueva narrativa hispanoamericana.

\section{ABSTRACT}

Unlimited in terms of publishing media and the migration of forms, a major shift has occurred in the reception of non-fiction by authors associated with the new "new" Spanish American narrative. Parallel changes are taking place generically, coinciding with paradigm transformations in humanistic disciplines. If previous authors affected changes in "essays," recent ones modify the cultural status of interrelated writings through journalism, academic periodicals, criticism, interviews and blogs, among others. Analyzing representative works by Abad Faciolince, Fuguet, Valencia, and Volpi,

* Profesor de literatura y cultura hispanoamericanas, Sacramento State University, Sacramento, Estados Unidos. Correo: corralwh@csus.edu 
this article examines (with Aira, Bolaño, and Agamben in mind) how that prose and culture are being redefined.

Keywords: Abad Faciolince, Fuguet, Valencia, Volpi, non-fiction prose/culture, new spanish american narrative.

Recibido: 10.11.11. Aceptado: 05.04.12.

U

NA ANALOGÍA ENTRE LOS nuevos "nuevos" narradores hispanoamericanos y sus antecesores inmediatos es la atención a la prosa no ficticia como manera de convertirse en una parte mayor de la cultura de la cual se nutren. Sus exiguos críticos no han sabido decidir de quiénes o de qué obras o formas ensayísticas se compone ese corpus que continúa representándolos, aunque no sea necesario fijar ese fluir irresoluto. El esmero de esa producción prevalece sobre cualquier interés estrictamente estético, por ser también una fuente habitual de entradas, tal vez mayor de lo que fue para sus a veces maestros "boomistas", cuando ellos estaban en una etapa análoga de sus carreras. En épocas de reivindicaciones, tampoco debe pasar desapercibido el magro papel de las narradoras en ese estado del arte.

¿Cómo jerarquizar entonces aquella producción habitualmente dispersa, incluso estar al tanto, y determinar su público? ¿Qué hacer si las obras no están consolidadas o canonizadas? ¿Cómo establecer ciertos parámetros de recepción cuando muchos de estos narradores publican continuamente en periódicos y revistas que además tienen sitios en la red? ¿Qué hacer cuando varios tienen sus propios blogs (particularmente las mexicanas Cristina Rivera Garza [1964] y Carmen Boullosa [1954], ambas con prosa ficticia no recogida, y el peruano Ivan Thays [1968])? Una manera de comenzar a contestar estas preguntas y establecer valores es limitarse a la ascendencia de las publicaciones impresas; pero hacerlo sería concentrarse en algunos narradores agenciados inicialmente por McOndo, el Crack, y Líneas aéreas. Otra traba, aun cuando su ensayística haya sido "alfaguarizada” en sus países de origen, es que hasta ahora no logran o se les permite una distribución mayor, impedimento reconocido.

En lugar de distinciones se tiene el culto de la interdisciplinaridad indisciplinada, una feroz mercadotecnia de la mitología del autor más que de sus ideas, y una crisis de modernidades que requiere nuevas ideas sobre el pasado y su relación con el presente. De los narradores recientes casi canonizados se salvan Bolaño (1953-2003) y César Aira (1949), recordando que sus seguidores nacen a mediados de los sesenta o después. Muchos publican 
artículos, biografías o textos biográficos, conferencias, crítica literaria (no dominios teóricos sin bautizar), crónicas, cuadernillos, discursos, ensayos formales, fascículos, introducciones, notas críticas, observaciones, opúsculos, periodismo por supuesto, presentaciones, prólogos y reseñas de cierta chispa e importe. Esa variedad también hace pensar en lo poco que se conoce la prosa no ficticia del hondureño Horacio Castellanos Moya (1957), y el gran valor de la ya publicada del mexicano Enrique Serna (1959), entre otros.

Los esfuerzos sostenidos evidentes están en el Bolaño de Entre paréntesis (2004); y en el Aira de Pequeño manual de procedimientos que recoge textos publicados entre 1981 y 2004 (2007, disponible sólo en portugués, pero de originales conocidos). Una manera de confirmar otras coyunturas y articulaciones es examinar la prosa no ficticia de otros narradores que cumple consistentemente con las varias condiciones mencionadas. Me circunscribo por ende al colombiano Héctor Abad Faciolince (1957), al chileno-americano Alberto Fuguet (1964), al ecuatoriano residente en Barcelona, Leonardo Valencia (1969), y al mexicano Jorge Volpi (1968) y sus variados "libros de ensayo", consciente de las interminables revisiones de la peculiaridad de las definiciones de esta calificación. Según los criterios y características de su narrativa señalados por Cedomil Goic (2009), los nombrados pertenecen a la "Generación de 1987" (98-104) y a la "Generación de 2002" (104-106).

Establecido ese trasfondo, una característica que une y reivindica a los cuatro prototipos es su dedicación a la "literatura de calidad" hispanoamericana. Es temerario precisarlo para autores que todavía tienen mucho que escribir; sobre quienes se puede argüir que son apolíticos, y que a diferencia de sus antecesores, siguen sin encontrar causa común con compromisos del pasado. En Mujer, sexualidad, Internet y política (2006), Jaime Durán Barba y Santiago Nieto concluyen que los nuevos jóvenes electores hispanoamericanos no se interesan en lo absoluto por la antigua política; ni les importa la ideología de izquierda o de derecha, preocupación que dejan a los intelectuales y a los viejos. Pero ser apolítico está relacionado estructuralmente a la creencia que niega, y es necesariamente una especie de creencia rival, no una verdadera liberación. Es más exacto proponer (Corral, 2009) que modelos literarios como los presentados -que podrían terminar siendo típicos de nuevo siglo- no se caracterizan por suponer que tienen pertinencia o sentido las antiguas taxonomías.

Tampoco es posible atribuir contextos de producción nacional análogos para todo narrador hispanoamericano, aunque sí se puede señalar grandes ensayistas antecesores para los elegidos, como Germán Arciniegas, Benja- 
mín Carrión, Octavio Paz, y otros pocos. Más allá de José Donoso y Jorge Edwards ¿cuál es el gran ensayista chileno a quien sigue o responde $\mathrm{Fu}-$ guet? No es fácil encontrarle un maestro como Bolaño (véase Goic, 2009, 100-104). Si esta consideración cambia la definición del género de acuerdo a ensayistas "estrella", también podría alterar el prestigio de la forma, convirtiendo a sus practicantes en dispositivos (ante tanta proliferación y acumulación de conexiones humanas), que de una manera $\mathrm{u}$ otra tienen la capacidad de asegurar, capturar, controlar, determinar, interceptar o modelar los discursos de narradores vivos y muertos, para parafrasear una idea desarrollada por Giorgio Agamben en su panfleto Che cos'è un dispositivo (2006). Someramente, la prosa/cultura no ficticia de los nuevos narradores sigue siendo espinosa de publicar, encontrar, jerarquizar y sobre todo conceptualizar, y es dable comenzar a rescatarla y elucidarla con sus mejores patrones actuales.

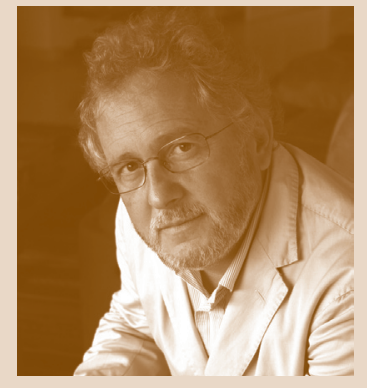

A. Faciolince

\section{ABAD FACIOLINCE Y LAS FORMAS COMPLEJAS}

Su primer "libro de ensayo", si se exceptúan el genéricamente sui generis Tratado de culinaria para mujeres tristes (1996) y la temática anticipatoria de Palabras sueltas (2002), es Las formas de la pereza (2007). Éste es mucho más, porque de los narradores de quienes me ocupo, Abad tiene mayor conciencia de que la pretensión de "leer mentes" es una forma decididamente baja del periodismo cultural, y un subtexto de su libro es elevar el listón de esa profesión. Por eso no le preocupa la obcecación de sus compatriotas con la angustia de las influencias, traducida como la obligación de hacer venias o criticar visceralmente a García Márquez; o convertir en estandarte la obsesión con los avatares de la violencia y el narcotráfico. En "Estética y narcotráfico" dice: "le rendimos culto al muy dudoso heroísmo de los asesinos; padecemos el hipnótico encanto de los sicarios, como si sus armas de muerte fueran, en vez de simples balas asesinas, rayos divinos de dominación. Antes había un temor reverencial por sus actos violentos; pero, ahora se leen con fruición sus palabras" (2008c: 518). Como ocurre en los otros narradores analizados, los márgenes de sus textos son borrosos, pero existen. En Las formas de la pereza Abad excluye, por ejemplo, textos concentrados exclusivamente en su país, no por mostrar una "nueva sensibilidad", sino por saber que así se llega a esa forma de pereza ensayística que es dialogar sólo con algunos lectores.

Para los de Las formas de la pereza que tienen que ver con el artista o con 
la vida intelectual, Abad optó por no reproducir "Las hazañas de una impostura" (1995), parte de una colección de testimonios colombianos sobre la bohemia. Hay allí una página referida a los años "bohemios" de García Márquez, según un testimonio de Plinio Apuleyo Mendoza, pero el resto es una tesis sobre ese estilo de vida en Occidente. Por encima del interés para la crítica politizada, que examine el tema en términos del sistema productivo, y que equipare al burgués con el bohemio porque ambos buscan la redención del éxito (1995: 27), la relación con Las formas de la pereza yace más en el enfoque sensato, sostenido y académico que Abad invierte en "Las hazañas de una impostura" sobre el artista heroico. Sin abandonar referencias localistas, recrimina en la cuarta parte de ese ensayo el facilismo con que se examina la bohemia desde el mito "tonto" del artista perezoso, y hay un párrafo al que no le falta nada:

Un criollo de los trópicos americanos, con finca y almacén, no verá en la bohemia más que sentimentalismo etílico e indolente haraganería elevada a nivel de obra de arte. Y si el criollo es, además, cosmopolita, dirá que lo que en París no duró más que unos decenios de mediados del siglo pasado, pasa a ser por estos ámbitos más provincianos una moda de duración e importancia exageradas. Y si el criollo crítico es también académico dirá que la bohemia es la caricatura más torpe del romanticismo, una especie de dandismo impotente que intenta darle cierta dignidad a la pobreza material y espiritual del artista mediocre. Babosadas melodramáticas y lloriqueos impúdicos, aptos para el teatro lírico, y nada más (1995: 25, énfasis míos).

Abad demuestra que se puede creer que establecer fronteras entre discursos o géneros es un tipo de esencialismo del cual los escritores que se respeten se deben distanciar. También sabe que ese argumento puede conducir a todavía otra forma de la pereza: una defensa de teorías esotéricas que pretende elevar el nivel del auditorio, o establecer un presunto compromiso dialógico para evitar reacciones robotizadas. Abad fomenta el arte de la provocación, distanciándolo del tipo de burla que puede caracterizar a un Fuguet, acercando su arte a un cuestionamiento ético, castigándonos por ser lo suficientemente ingenuos de creer en nuestras propias mitologías. Su par ensayístico y compatriota Juan Gabriel Vásquez (1973) fija bien una actitud presente en el resto de estos narradores. En "El tiro en el concierto: política y novela en Colombia", al hablar de cómo un capítulo de Asuntos de un hidalgo disoluto (1994) de Abad transmite magistralmente la obsolescencia y facilidad de manipular los discursos de derecha e izquierda,

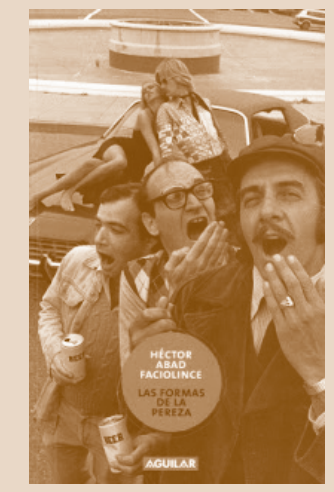


Vásquez afirma: "Se trata -espero que esta aclaración sea innecesaria- de una parodia. Pero esta parodia de diez páginas, situada en el contexto de esta breve novela de doscientas, formula, mediante métodos que aquí no puedo analizar, un retrato de la política colombiana más certero que la más comprometida e indignada novela de la Violencia" (2009: 107).

En la prosa no ficticia de Abad hay una dinámica centrada en cómo templar el sentimiento con el comportamiento, y por ende, si hay lecciones, son de cómo pensar y sentir, en vez de cómo vivir. Para él, la "pereza" es una serie de formas, ninguna de las cuales tiene que ver con el bloqueo del escritor. La cuarta de sus "Trece tesis sobre periodismo y literatura" afirma que "La literatura existe no sólo para que haya una escritura narrativa que se libere de las amarras de los hechos, de la dictadura de la realidad, sino también para poder penetrar en lo más íntimo y recóndito del ser humano sin hacer pornografía" (2007: 117-118). En una entrevista asevera además: "La ficción existe porque la verdad verdadera es insoportable, si se la usa a toda hora: el periodismo no puede hablar de la vida privada de las personas; para hablar de la vida privada está la literatura con personajes ficticios" (Escobedo Prieto, 2010: 115). Como Valencia y Volpi, recurre a los clásicos españoles, y a Borges y Vargas Llosa, para aseverar en "El peligro de leer libros (¿qué hacer con la literatura?)" (2007: 161-174) que conservamos un tesoro ilustre, "Y no porque seamos puristas apegados a una tradición, ni nostálgicos monárquicos de la 'madre patria', sino porque transmitimos las cadencias de una ilustre construcción cultural de siglos, adaptada a nuestras nuevas y cambiantes realidades" (2007: 172).

La postura anterior no le ganará fanáticos a Abad en la academia anglosajona, o en la latina que la calca para estar "al día"; pero no importa, porque, como los otros narradores, no escribe para los especialistas. Reitero que las opiniones de esta generación no son estrictamente apolíticas, y que no siguen las directivas de cierto academicismo latinoamericanista comprometido. No obstante, Valencia y Abad demuestran estar al tanto de la crítica especializada, y son objetivos respecto a la política. Precisamente, en "La literatura como peste" (2007: 83-92) Abad elogia la visión de los comparatistas comprometidos Franco Moretti y Fredric Jameson respecto de la difusión mundial de la novela moderna, por medio de transacciones entre experiencias locales y patrones occidentales (2007: 87).

Esta apertura está ejemplificada magníficamente en el extenso "El devorador de libros" (2007: 183-196), y "Un libro abierto" (2007: 197-209), plantillas para lo que dice en otros sobre la lectura. Como los mejores en- 
sayistas, un par de pensamientos, lecturas, anécdotas o historias personales o de otros siempre le recuerdan algo más inteligente o interesante, o aun mejor, contradictorio, o un libro. La televisión aparece y reaparece como su bête noire favorita, a no ser que se exceptúe el nacionalismo pobre. La sensatez también surge constantemente, y afirma "quiero decir que si uno nació en Medellín, no debe empezar leyendo a Robbe-Grillet, y que si uno nació en Borgoña sus primeras lecturas no han de ser San Antoñito y la Marquesa de Yolombó" (2007: 204). Y aunque en "Notarios en una guerra de familia" (2007: 127-131) alega que un periodista de opinión no puede tomar partido (2007: 130), en el genial y fulminante "Por qué es tan malo Paulo Coelho" (2007: 211-218) hace todo lo contrario, y dice lo que muchos sienten (si esto es tomar partido, la fuerza de su argumento lo hace aceptable). En este ensayo, que cierra Las formas de la pereza, no hay evasiones, se sigue a sí mismo, y su mirada es la misma que en otros textos: contraria, divertida, ecléctica y no siempre irónica.

Vuelvo momentáneamente a una idea relacionada a las formas que en Idea della prosa (1985) Agamben considera en desuso: el desdén no siempre mal intencionado hacia la prosa que viene de cierta periferia, que en el caso de Abad sirve para mostrar la continuidad entre su ficción y su prosa no ficticia y en el de Volpi para exagerar la debilidad de su mejor obra ficticia. El colombiano publicó un texto que Letras Libres incluyó en un dossier titulado, con poca ironía, "Borges inédito". La relación entre este texto, ya publicado en Colombia, y su novela El olvido que seremos es evidente en su ensayismo, con la plusvalía de una trama detectivesca viable de llamar borgeana ${ }^{1}$. Abad publicó un adelanto de su artículo en la revista ecuatoriana $E l$ Búho, para luego sacar una adaptación más extensa, aunque con un título (¿suyo?) más sentimental en la edición mexicana de Letras Libres. Ahora, todos esos textos sobre Borges, el más mentiroso de nuestros autores, son parte del libro Traiciones de la memoria (2009b). ¿Cuál versión llegará a más

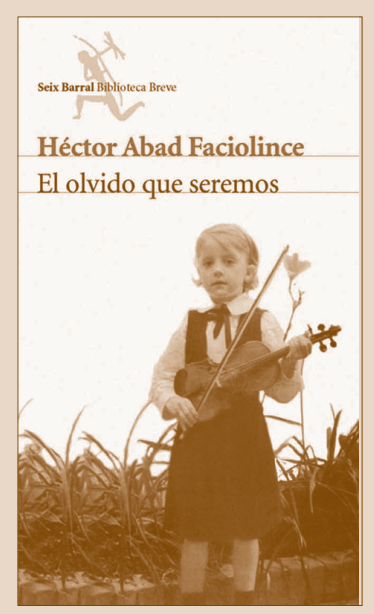

Héctor Abad Faciolince El olvido que seremos

\footnotetext{
${ }^{1}$ En su elogiosa lectura de ella y Traiciones de la memoria Vargas Llosa (2010) compara el mundo de Abad al del Onetti de El infierno tan temido y La vida breve, valorando la sutileza y belleza de los libros de Abad al no ficcionalizar la violencia política colombiana. Por ese enfoque y el alcance universal sobre la condición humana que provee el colombiano es difícil compartir la opinión de que "La desdicha de Traiciones de la memoria para el lector mexicano es la ausencia de su antecedente directo, El olvido que seremos [...] implacable requisitoria contra todo un país y sus taras" (énfasis mío), según la reseña de Alberto Román, "Se los tragó Colombia” (2010, p. 84). Toda traducción posterior es mía, excepto donde se indique lo contrario.
} 
lectores? La pregunta es casi retórica, y no tiene nada que ver con la calidad del artículo o esas revistas, sino con el tipo de comercialización que Abad critica en varios textos suyos.

El texto ecuatoriano es igualmente autobiográfico, pero más literario: "Aspiramos a traducir la vida viva, la vida mojada de lluvia y caliente del sol, la vida de las caricias y los gestos, la vida elemental en que se camina, se copula, se come y se llora” (2008a: 46). Esa es la vida que también recoge en Las formas de la pereza. Si "Un poema en el bolsillo" es un relato ensayístico que se lee como un cuento, "El olvido que purifica, la memoria que elige", título de la versión de El Búho, es una expresión cabal del modus operandi de su prosa no ficticia, con definiciones sobre la literatura y la realidad (2008a: 47), coadyuvadas con dictámenes como "Difumino y aumento, exagero y disminuyo, borro y muy pocas veces añado algo tomado de otra escena, robado a otro recuerdo a otro olvido" (2008a: 47). Esa realización admite errores, aunque sean insignificantes.

Discutir el ensayo anterior es una parada importante para entender su práctica, porque en la tercera y última parte del texto de El Búho vuelve al tema que había elegido para la conferencia que fue su texto: cómo "novelizó" la muerte de su padre. Afirma: "He escrito y seguiré escribiendo tal vez cómo encontré [ese poema], porque es una obsesión, pero no la escritura de un recuerdo personal, sino la escritura de algo casi incomprensible. Es la escritura de un olvido, la reconstrucción, por indicios, de un recuerdo" (2008a: 49). Le precisa a Escobedo Prieto: "Lo que la gente llama fantasía, tal vez no sea otra cosa que un juego de recuerdos mal recordados, de olvidos mal olvidados, de vivencias transformadas por la desmemoria, e incluso de eso que quienes creen en la reencarnación consideran que son remembranzas imperfectas de otras vidas" (106). En "Literatura, compromiso y moral", Babelia 1000 (27 marzo 2011), breve entrevista posterior, expresa que a pesar de que no hay vidas ejemplares, o literatura moralista actualmente, "Por mucho que la novela no tome partido, los dilemas morales son parte esencial del quehacer literario" (3).

Ese andamiaje se complica en Traiciones de la memoria, relatos compuestos de autobiografía, cuento y ensayo, según el autor y la editorial. El primero, "Un poema en el bolsillo" (2009b: 15-185) es la versión ¿¿definitiva? del ensayo que he examinado. Los otros dos, "Un camino equivocado" (2009b: 187-241) y "Ex futuros" (2009b: 243-265) son autobiográficos, y llamarlos "cuentos" o "ensayos" es caer en la trampa de exigir a los géneros lo que no siempre pueden o quieren dar. En el "Prólogo" explica cómo estructura esos relatos, casi codificando cómo debemos leerlos: "Lo ya ocurrido y lo 
que está por venir, en mi cabeza, son apenas conjeturas. Los relatos autobiográficos que componen este libro tienen esa consistencia mixta" (2009b: 12). Y luego de expresar que fueron publicados antes en versiones más cortas y "rudimentarias", asevera "Aquí están corregidos, menos incompletos, y, en algunos casos, con el material visual que me ayudó a rescatarlos de la confusión y la desmemoria" (2009b: 12).

Sus recuerdos y especulaciones añaden un carácter documental a Traiciones de la memoria. Pero el autor es demasiado listo, y la constante relación de historias personales demuestra que las elecciones que asume un escritor son el mensaje ulterior y más importante. Abad quiere mostrarse como obsesivo en el primer relato, y el resultado es que el Borges de las versiones anteriores se convierte aquí en vademécum y Baedeker de un periplo ampliado. Es tal la fuerza de ese "gran relato" que los dos restantes parecerían suplementos de aquella historia. No es así, porque si para él las opiniones políticas personales siempre tienen que ser objetivas, el gatillo en "Un camino equivocado" es un exilio político agravado por no quiere olvidar la muerte de su padre. Su honestidad en las cinco subsecciones de este relato es envidiable, e incluye cándidamente las penurias de su estadía en Italia y alguna indiscreción (2009b: 232-241), y su lucha interna sobre qué hacer con su vida. Acopla también subrelatos sobre música, un reloj, su familia de entonces, párrafos hilarantes sobre cómo se va a hacer pasar por español para que los italianos lo acepten como profesor de clases privadas (2009b: 224-228), y sobre todo la hipocresía y contradicciones que pueden definir la visión extranjera de la política hispanoamericana.

Ese tercer relato no puede ser otra cosa que una manera de cerrar, por ahora, todas esas memorias y confesiones, incluso las de otros libros. En él Abad parece analizarse literariamente, comentando desde el principio "Creo que el primer requisito para poder escribir una historia ficticia (y también la primera condición para leerla con gusto) consiste en la capacidad de desdoblarse, de salirse del soso yo que nos habita" (2009b: 245). El resto del "ensayo de género incierto" (ya no es "relato") está poblado de dictámenes generalmente existencialistas sobre el escritor y su quehacer, y dedicado sobre todo a los caminos que no tomó, los ex-futuros (2009b: 252-257) que son como fantasmas (2009b: 259). En verdad la memoria no traiciona a Abad, porque es demasiado honesto como literato, y separar esas cámaras mentales nunca puede ocurrir a la perfección, porque nunca disfraza su franqueza con retórica transparente. Más bien, como los narradores que discuto a continuación, Abad sabe que hoy nos construimos las historias, y que en el nuevo orden narrativo la persuasión de éstas ha pasa-
HÉCTOR ABAD FACIOLINCE TRACLOHWES DELL MEMORIA

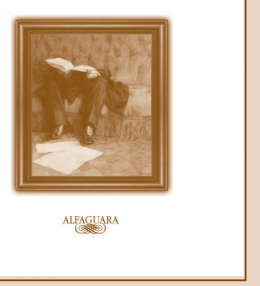


do de la publicidad a las mentiras de la literatura, porque en las sociedades actuales todo se ficcionaliza².

\section{FUGUET Y LA LEVEDAD DEL NUEVO NARRADOR “BILINGÜE”}

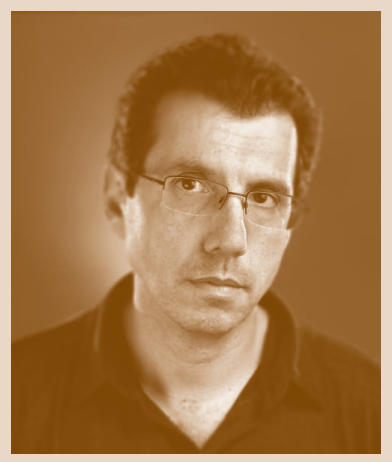

A. Fuguet
Sin duda, la prosa no ficticia de Fuguet es fiel a los títulos de sus colecciones. Las que tenemos no son una autocrítica razonada sino una especie de performance para parecer más cool, diría él (cuando podría decir sereno, tranquilo, o seguro de sí mismo), porque en realidad le interesa ser interesante. Pero también se revela perplejo, y frecuente e intelectualmente frívolo, en cuyo caso sus pares light serían el argentino Rodrigo Fresán (1963) y el boliviano formado en los Estados Unidos, Edmundo Paz Soldán (1967). La pose tremendista o defensiva puede deberse a la presión generacional por figurar, y esa frivolidad se da más cuando "Fuguet y Cía. Ltda." escriben para periódicos que, peregrinamente, todavía les abren sus páginas. Son desplantes que desafortunadamente caracterizan una nota zalamera de Rioseco sobre esta prosa de Fuguet, cuya única novedad es referirse descriptivamente a ella y decir que, en última instancia, lo que escribe Fuguet es "literatura" (15). Más que sus coetáneos y los otros discutidos aquí, Fuguet no proyecta la necesidad de explicar su arte sino su persona o figura, admitiendo por extensión que tal vez sea más de lo último que lo primero. Si se quiere ser categórico respecto a apuntes autistas (así, en minúsculas) se podría decir que cuando polemiza con una idea o individuo no lo hace meramente para ganar o perder un argumento, sino para probar que existe.

Por ende, sus frecuentes intentos de ficcionalizar su ensayística dependen demasiado de la contingencia de significados y referencias, produciendo una colisión entre lo fantástico y lo prosaico. Esa actitud no adquiere hasta hoy el sentido trascendente que notaba Alberto Zum Felde en 1954 para Borges: "El ensayista puede ser tan fantástico como el cuentista, y también tan perfecto artista como él" (580), haciendo hincapié en que "El ensayista, como el cuentista, maneja con igual inventiva y gracia desde los más antiguos y preciosos datos eruditos, extraídos, al parecer, de los 'raros

${ }^{2}$ Este desarrollo explica el éxito, sobre todo en la cultura anglosajona, de un libro serio y ameno, The Seven Basic Plots: Why We Tell Stories (2004), de Christopher Booker. Esta progresión se desarrolla plenamente en Christian Salmon, Storytelling. La máquina de fabricar historias y formatear las mentes, trad. Inés Bértolo (Barcelona: Península, 2008), sobre todo en la introducción (27-41) y en el capítulo 2, "La invención del 'storytelling management"” (65-92). 
infolios', hasta los inmediatos de la literatura y la ciencia contemporáneas. Lo sabe todo (o parece que lo sabe)..." (581).

Por razones contrarias a la capacidad señalada por Zum Felde suponía que examinaría la prosa/cultura de un autor antipático, que va contra una de las normas que enfatiza a través de su colección: la obvia necesidad de separar autor de obra. Pero al tratar o retratar lo personal, Fuguet es el más cándido de los estudiados, evidente en el excelente y conmovedor relato, crónica, historia, o biografía (así lo califica en varios momentos) "Perdido (Missing)" (2007: 357-374), sobre un tío que se abandona a la droga, a sí mismo, se aísla de su familia, y, que se sepa, del mundo. No es casual que termine sus apuntes autistas con ese texto, adelanto muy expandido y convertido en Missing (una investigación) (2009). En el texto de base transmite que la creatividad es una actuación en que el artista intenta liberarse de las expectativas culturales, morales, políticas y psicológicas de la sociedad. Pero en la versión definitiva no logra esa meta. El cuarteto escogido comparte ese deseo de no ser sumiso al mundo, y Fuguet es el más visceral e imperfecto, pero no menos valioso, sobre todo porque se vislumbra la posibilidad de otros logros, aun cuando la crítica ya ha notado los defectos de Missing, de los cuales no es el menor la insistencia en expresar en inglés términos comunes en español.

Al comienzo y al fin de apuntes autistas Fuguet expresa su preocupación sobre el "género" al que pertenece, y esa inquietud sirve como sujetalibros conceptual de su colección. Al final, en una página totalmente aislada y en cuerpo menor, dice: "Estos apuntes, crónicas, escritos, columnas y textos se escribieron en muchas partes. Demasiadas" (2007: 383), agradeciéndole a su agente por entender que "un narrador es un narrador, da lo mismo que escriba o filme" (383). En la "Nota" con que se abre el libro, asevera: "Soy un narrador, a veces por escrito, a veces visual, a veces periodístico" (2007:9), establece su arbitrariedad discursiva, y afirma que no sabe qué tipo de libro es apuntes autistas, y que tampoco le importa. Amplifica: "Creo que se trata, de alguna manera, de cuentos cortos sobre hechos reales. O ensayos sobre temas que me interesan. Todo es en primera persona" (2009: 10), para terminar con el cliché "Mi casa es tu casa". Sus textos desplazan los géneros, ¿y qué? Tampoco es curioso que sus referentes casi siempre son literarios o cinemáticos, y decididamente anglófilos, como en "El sonido del silencio" (2007: 57-60) y "Austin revisitado (la cultura de no hacer nada)" (2007: 61-71)

\footnotetext{
${ }^{3}$ Rioseco (2010) no analiza sino que enaltece ese enfoque, sin el contexto del de otros narradores. Al aseverar que su intuición le indica que estos libros son "para la gente que entendió que
} 
A pesar de esa indeterminación, él (o sus editores), ordena su libro de acuerdo a actos relacionados a varios privilegios del intelectual inorgánico, si se cree en esa definición: "Viajar" (2007: 14-75), "Mirar" (76-163), "Leer" (164-262) y "Narrar" (264-374); y vale tener en cuenta las obvias relaciones entre esos temas generales cuando los enfatiza un narrador. De la misma manera, como con los otros prosistas que analizo, desmenuzar cada texto suyo sólo conduce a caer en la trampa del texto híbrido, que se puede dar por sentado como el modus operandi preferido pero no exclusivo de cada uno de los narradores que examino. Como su ficción, la prosa no ficticia de Fuguet está llena de metáforas sobre su condición de ¿permanente? escritor "rebelde", y se granjeará el cariño de una nueva generación de universitarios neurasténicos, lo cual limita su alcance a un grupo no curado del acné o aficionado a varios tipos de clones posmodernos que en verdad ya han pasado de moda.

Si apuntes autistas es una justificación autobiográfica de sus intereses, esa perspectiva se nota más en las notas sobre unos pocos escritores "chilenos", o sobre su relación con las lenguas en que se expresan. Son coordenadas que se mezclan, porque al escribir sobre Ariel Dorfman o Isabel Allende -autores cuyo único parecido es haber sido chilenos, vivir en los Estados Unidos e insistir en que escriben directamente en inglés- es como si escribiera sobre sí mismo. Los une su imprecisa relación con Chile, y en el caso de los dos mayores, el desprecio de algunos compatriotas. Es complejo descifrar esta situación, porque se trata de tratar de separar autor de obra objetivamente. El texto sobre y en co-autoría con Dorfman, "Confessions of an unrepentant exile" (2007: 233-241), está escrito en una especie de spanglish (véase también "Tratar de estar mejor", 177-179), aparentemente por insistencia de Dorfman, y el patético resultado no contribuirá a que Dorfman sea menos despreciado por algunos chilenos, por quienes dice no sentir ningún cariño, y le da igual. Esta actitud los enhebra, con una que otra diferencia, desde una visión conservadora que se pretende ilustrada, como deja claro Fuguet en "Cómplices" (2007: 353-356).

Como se sabrá, en 1996 Fuguet aparece en el firmamento literario con la polémica antología McOndo, que compila con Sergio Gómez (1962), y pre-

los ochenta existieron" (17) y que Fuguet escribe para él (aparte de sobrevalorizar el "nosotros" en sus páginas), por ser un contemporáneo "con quien sería placentero discutir el debut de una película reciente" (17) no hace otra cosa que restringir de manera simplista el público al que "debe" llegar Fuguet. 
senta a contemporáneos como Valencia, no Volpi. Fuguet, cuya mala onda entre su generación comenzó al asesinar mal al "realismo mágico", coadyuvado por diatribas oportunistas de Paz Soldán o el mexicano Ignacio Padilla (1968), no habla aquí de Allende u otros coetáneos o mayores más logrados, entre ellos Alejandro Zambra (1975) y Donoso. En este proceder interviene nuevamente la autobiografía, porque Fuguet se formó en los Estados Unidos, sus referentes culturales son casi exclusivamente de ese país, y sólo ahora parece estar descubriendo sus raíces, ya instalado en Chile. Pero se siente desguarnecido, y son múltiples las veces que sus testimonios se refieren a la soledad. "La pega de uno (escribir, ayudar, salvar)" (2007: 281284), escrito en inglés, y "Yo hablo español” (285-288), revelan fuentes de esa incomunicación, mas no que la condición descrita es común para cualquier emigrante aculturado en los Estados Unidos. Así, un error de Rioseco es presentar la presunta "rebeldía" de Fuguet como el descubrimiento de la pólvora, respecto a los estereotipos europeos y estadounidenses del latinoamericano, añadiendo el simplismo de que los narradores anteriores no le permitían a los lectores la "libertad" que tienen ahora (2010: 18).

En Fuguet es patente que el secreto para una prosa ficticia memorable es con frecuencia la predisposición del escritor para ser sorprendido. De estos textos -muchos de los cuales muestran su preferencia por la "ficciónficción" de manera conservadora, acudiendo a los "clásicos" y su admitido prejuicio "anti-moda" (2007: 211) - el más sostenido, como literatura y crítica, es "Voceros (todo está en todo)" (2007: 189-200). La lectura de apuntes autistas y Missing puede dejar la impresión de que, más allá de su fijación autobiográfica, Fuguet quiere mostrar en ellos su progresión en la prosa no ficticia. No es así, y tal vez se deba a lo que he llamado en otras partes "la condena de la edición nacional". El hecho es que a finales del 2000 publicó más de medio millar de páginas dedicadas a la cotidianidad fílmica, literaria y vital con el título Primera parte, y ésta muestra las mismas fallas que las colecciones posteriores, como si él (y obviamente sus editores) no hubiera aprendido de sus errores.

Si se puede decir que los textos de Primera parte son precursores, es sólo en el sentido temático, no conceptual. Rioseco postula que ese libro y apuntes autistas "no permiten la nostalgia. 'Todo era peor en el pasado'. O algo así [sic]" (2010: 17). En la introducción al libro, llena de disculpas por ser un "adelantado" y reconocimiento de deudas a su editor (2000: 13), provee una lista de sus colecciones favoritas de artículos periodísticos, que "son un género en sí. Mitad no ficción, mitad ensayo, los buenos compilados se leen siempre como una novela más del autor" (2000: 10), y todas, con 


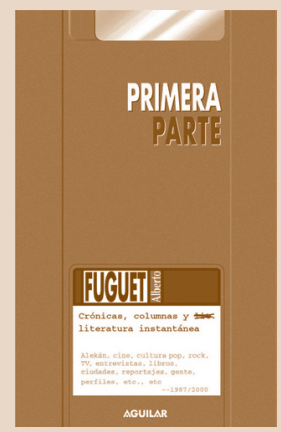

la excepción de las de Fresán y Osvaldo Soriano, son de "boomistas", entre los que sobresale Donoso. El título se refiere a su "primera parte" como periodista, escritor y persona, y concluye que "Segunda parte y, ojalá, Tercera parte serán los de un escritor que desea hacer periodismo" (2000: 11), porque la primera "es el libro de un periodista con ganas de ser escritor" (11). Astutamente, Fuguet se adelanta a la recepción de su tomo. Sin embargo, la honestidad de esa introducción resulta ser falsa modestia en el resto del volumen, y también está socavada por una práctica ficticia anterior, su novela hecha película, Tinta roja (1996), en que el protagonista Alfonso Fernández, autor ya maduro y exitoso, se pregunta si su primera vida como periodista en verdad fue la de un perdedor cínico, ayudado por un padre putativo tal vez peor que él.

Primera parte muestra consistencia en su lealtad, por ejemplo, a Vargas Llosa, en "Súper Mario" (2000: 142-144) y el interesantísimo (por su tesis sobre la relación maestro-discípulo, y su anticipo a los temas de Travesuras de la niña mala) "Mario Vargas Llosa: La ciudad y los huachos" del 2000 (396-405). En ambos, como en la alusión al juego de vídeo, la contemporaneidad cultural se conjuga con comentarios políticos, y no falta el spanglish en textos como "24/7" (2000: 406-414), en que se ve obligado a tratar de traducir o explicar neologismos relacionados a la cultura digital. No obstante, y esto es por lo menos una paradoja, en "Se habla español" aboga por el español como segunda lengua franca de las Américas (2000: 247). Si en términos geopolíticos esa situación es un hecho, también es una exageración creer que todo el continente, incluso sus jóvenes más aculturados, es bilingüe.

A pesar de que un hilo de Primera parte es la reacción de Fuguet al milenio, la cultura visual y auditiva y la "sabiduría pop", definida en "Jaip", "Posers" y "Ser freak (Raro)" (2000: 173-180), y que según él definirán este siglo, la literatura (sobre todo la estadounidense contemporánea) nunca deja de atraerle, y jamás de manera convencional. No obstante su deseo de progresar, el Fuguet de Primera parte es el de hoy, y aunque el reciente Missing parece ser una buena parada, es el mismo camino que ha tomado para pasear su prosa no ficticia. Missing tiene una portada genial. Leída semióticamente, el tío Carlos Fuguet encarna todo lo que significó los setenta, para los Estados Unidos: traje horroroso de poliéster, un latino blanco de pelo largo y bigote, fotografiado con una cinta de "Mr. U.S.A.", y enarbolando una banderita estadounidense de papel. No estaba muy de moda en esos años que un latinoamericano se entusiasmara con otro metamensaje de la foto: un sueño americano patético. 
Como decía respecto al anticipo publicado en apuntes autistas, hay algo conmovedor en esa historia, y para cuando dice de la entrevista con el tío "A los días supe que este sistema no iba a funcionar. Carlos se transformaba en otro y no me gustaban sus respuestas. No me servían. Tampoco me gustaban mis preguntas. Había tensión, silencios y poca comunicación" (2009: 131), ya estamos convencidos de que Missing es más sobre el sobrino. El libro tiene nueve "capítulos", y del quinto al octavo es una serie de poemas conversacionales que narran las vicisitudes de Carlos, como una $\mathrm{La}$ Araucana al revés. Otra vez, el spanglish gana, sobre todo en el quinto, titulado "The Echoes of his mind. carlos [sic] talks", y se repite los descuidos lingüísticos del proto-texto, incluso en los epígrafes colocados al principio del libro, sin que los lectores sepan a quién atribuir los errores. Se puede suponer que el autor quiere que los lectores capten la alusión a la canción de Harry Nilsson "Everybody's Talkin", que sirvió de fondo para la película de 1969, presentada en español como Cowboy de medianoche. ¿Supone Fuguet que todos sus lectores están tan americanizados como él, o que son de su edad? Si es así, su libro demuestra que la prosa/cultura popular también sufre de esnobismo.

Del tercer capítulo al quinto la tipografía reproduce textos escritos a mano, tipos empleados para correos electrónicos, cartas, notas y facsímiles afines. Rastrear la presencia del bilingüismo forzado es tan engorroso como leerlo otra vez, pero vale reiterar el apego de Fuguet a modelos literarios, sobre los cuales parece pensar constantemente. La narración que justifica la investigación que se supone es Missing se concentra en los capítulos cuatro a seis. Este, titulado "All American Slam. conversando en el Denny's on Federal", que exige traducción de ciertas costumbres gastronómicas típicas de los Estados Unidos, se refiere a otra conversación con el tío: “El motivo: hacer un libro. O que él me contara su historia y esa historia, unida quizás a la crónica de Etiqueta Negra, podría convertirse en una narración [...] Sí; vivir para contarla. Pero que lo contara él. Colocar todo lo que había pasado, registrar mi investigación, hacer un testimonio" (2009: 125). Si esa fue la intención, Missing no llena los baches o une los puntos suspensivos, y no sólo por el exceso de alusiones populares estadounidenses que, a la larga, les importan un bledo a otros lectores del continente.

Si el noveno y último capítulo es una conclusión agridulce (estropeó la película al decir que el tío vuelve y vive, para ser usado), también ofrece otra conclusión: el bilingüismo es aceptado plenamente, y las frases en inglés ya no vienen en cursiva: es el "sueño americano" del autor, cumplido, para él, no para su tío, que aparentemente vivirá el suyo como pesadilla, perdido. 
Vargas Llosa es demasiado benévolo al valorar la hibridez de Missing, particularmente considerando su propia práctica ${ }^{4}$. Se puede tomar muy en serio Missing, el libro, como un documento humano profundo, sin considerarlo un documento literario de gran profundidad, a pesar de los registros dialectales con que Fuguet se he entretenido por lo menos desde Tinta roja (1998). Goic, hablando de ésta, menciona una característica aplicable a la ficción posterior: "La obra carece del estricto determinante novelístico del género, como no sea la novela de formación o su contrario, y diluye la acción interrumpiéndola [...]" (2009: 100).

Fuguet se ha convertido en un pararrayos mayor al bucear osadamente en materias o personajes improbables, con poco más que una corazonada lingüística respecto a lo que va a encontrar. Es una valentía diferente de la de Abad o Valencia, pero no deja de ser una temeridad poco común, de resultados generalmente positivos. Como los otros, aunque con mayor ahínco, Fuguet sigue luchando con cómo la transacción entre narrador y materia se puede manipular fácilmente para bien del mercado, con momentos exagerados para guiar a los lectores hacia ciertas emociones, euforia o perspicacias predestinadas. En estos casos la prosa, ficticia o no, adquiere con frecuencia el peso de diferentes tipos de sentimentalismo, el gran enemigo de la buena escritura. Este no es el caso de la gran mayoría de los narradores que voy discutiendo, aun tomando en cuenta que aquella sensibilidad es más difícil de evitar mientras va creciendo su fama. Examino entonces una inteligencia que se ordena ágilmente, de otra manera.

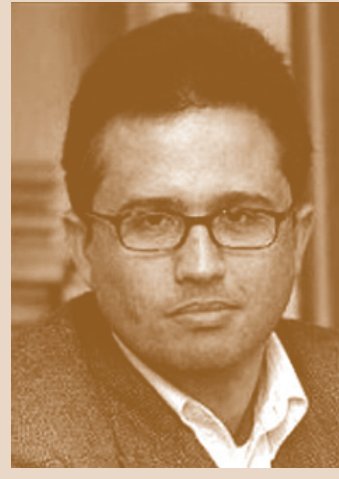

J. Volpi

\section{VALENCIA Y LA AUTORREFERENCIALIDAD CRÍTICA}

Diferente de Fuguet, con Valencia no hay que ir página por página para demostrar conexiones conceptuales, porque el ecuatoriano piensa y escribe con mayor ambición y sin la inseguridad del neófito. Porque también evita exabruptos del tipo "uno de mis autores favoritos", o las pontificaciones del tipo "en esto creo, y punto", con Valencia, como con Abad, se está ante una especie de sesudo atleta literario en una época de distracciones electrónicas

\footnotetext{
${ }^{4}$ Respecto a la hibridez lingüística no es menos generoso al decir: "Este estilo no es una caricatura ni un preciosismo formalista, es un estilo persuasivo y funcional [sic], porque delata a través de su manera de hablar lo que son quienes así se expresan, la inseguridad que los habita, el inconcluso mestizaje cultural y lingüístico que constituyen, los dos mundos que hay en ellos coexistiendo con aspereza y sin llegar a fundirse" (Vargas Llosa, 2011: 5).
} 
y especializaciones voluntariosas, laboriosidad casi decimonónica, parecida a la de un blogger en su aparente determinación por convertir cualquier trozo de conocimiento y experiencia en palabras. De hecho, Valencia mantiene un $b \log$, factor que en su caso enriquece cualquier lectura de su prosa no ficticia, su narrativa y su actividad literaria, que lo ubican como uno de los prosistas más dinámicos de su generación. Tomadas en cuenta las debidas diferencias, en él y en Abad es notable un proceso de depuración y perfeccionamiento de las ideas que les sirven como plantilla, aun cuando Valencia las expresa en un medio relativamente transitorio como un blog.

Esa visión dice mucho sobre la nueva "nueva" narrativa del continente, y tal vez demasiado sobre sus autores, aquellos cuya ficción comenzó a llegar a las librerías a mediados de los noventa. En el caso del ecuatoriano las condiciones del exilio voluntario proveen matices que en otros se convierten en estereotipos para intérpretes. Las razones, iremos viendo, no son difíciles de aceptar: poco de la prosa de narradores que comparten una especie de exilio similar al de Valencia vale la pena, aun considerando que esa escritura sigue dispersa. Paralelamente, aun cuando aquélla no tiene la atractiva seña de identidad del exilio político, es incierto que las editoriales que les publican su ficción quieran arriesgarse con otro género. No obstante, por lo general hay un talento innegable en esa prosa, mucha de la cual cruza las líneas genéricas establecidas para producir crítica incendiaria, ensayos, notas académicas o artículos, y obras periodísticas. El síndrome de Falcón de Valencia (2008a) es un libro singular para esa práctica, y sus pares serían las colecciones ya mencionadas de Aira y Bolaño, Abad y algo de Volpi. Por razones que superan cierto tono de ajuste de cuentas cuando hablan del mundo literario, estos ensayistas también han sido vistos como polemistas, calificación insuficiente en la historia de las ideas.

Identificado inicialmente con $\mathrm{McOndo}$ y muchas otras colecciones que presentaron al grueso de estos narradores a un público mayor, Valencia ha dejado atrás a su cohorte en términos ensayísticos. Como varios de sus coetáneos más sensatos no muestra ningún desprecio hacia las bêtes noires del posmodernismo: el canon occidental o algunas ideas de la Ilustración; ni tampoco hacia híbridos estéticos, nuevas formas narrativas, culturas u otras artes. Y lo hace con claridad de pensamiento y expresión. Esas son las coordenadas que hacen un placer y desafío leer El síndrome de Falcón. Junto con Abad, Valencia es el narrador más literario, como estilista y por acercarse a la literatura como un deber que en otra época era el privilegio y monopolio de algunos grandes filólogos europeos y políglotas "tradicionalistas" de Nuestra América. Consecuentemente, no hay tecnicismos o pesadumbre 
en su prosa abierta, porque sabe que el mundo cultural nunca ha podido o debe ser estático.

El título de su colección alude a un hecho verídico: por falta de una silla de ruedas, Juan Falcón Sandoval cargó sobre sus hombros por doce años al escritor socialista ecuatoriano Joaquín Gallegos Lara. Éste despreciaba toda literatura que no fuera comprometida, según su definición, y por ende criticó severamente a dos de los mejores escritores hispanoamericanos de su momento (los años veinte y treinta), sus compatriotas Pablo Palacio y Humberto Salvador. Éstos fueron condenados al ostracismo cultural por no adherir al realismo social, o a la política hoy llamada "progresista" que ha vuelto a ser una norma que parece muy de derecha en su país. El peso de ese pasado ha sido y ha vuelto a ser en este siglo uno de los mayores problemas de la literatura ecuatoriana, y es obvio que sigue siendo una bête noire principal de Valencia. En ese ensayo y otros cuatro de la sección "Sobre literatura ecuatoriana", arguye brillante y valientemente contra la fijación politizada de ver al escritor como portavoz del "pueblo", y observa y se dirige a complicaciones mayores.

La primera sección, "Sobre escritores", es prueba fehaciente del lugar que debe ocupar en lo que se da por llamar "Nueva literatura mundial", etiqueta que todavía define a un tipo de narrativa escrita principalmente en inglés. Valencia se manifiesta desde ese contexto acerca de autores hispanos, entre ellos Borges, Cortázar, Vargas Llosa, Vila-Matas y Aira, y en estos artículos se notan diálogos y querellas positivas con los maestros que sabe escoger. Para él, como para Abad, Vásquez y Fuguet, el peruano se ha convertido en un modelo más intelectual que pedagógico ${ }^{5}$. Conjuntamente, escribe con autoridad e igual admiración sobre los italianos Lampedusa y Buzzati, el griego Adonis, contextualiza mundialmente al novelista inglés Ishaguro y

${ }^{5}$ Mucho antes del Nobel, en ocasión de Cartas a un joven novelista, Valencia y su cohorte escriben "Respuestas a Vargas Llosa de 10 novelistas jóvenes de Hispanoamérica", 1998, pp. 4-9. Hay en ellas un tono admirativo, novísimo, franco, desfachatado, combativo, e inteligente. Las más perspicaces son las de Valencia (8), Fresán (4-5), y Thays (8-9). En "Gratitud crítica" el ecuatoriano valoriza Cartas... como fusión de saberes novelísticos, rechaza el nacionalismo irreflexivo que agobia al talento individual ante la tradición de su propio país, y ve en el maestro un estímulo ejemplar con el cual medirse, más que un obstáculo: "Y por eso no comparto la voz de ese coro que se dedica a desprestigiarte" (8). Esa opinión no le impide ser objetivo con la técnica del peruano en "Mario Vargas Llosa: el guardián ante el abismo", 2005, pp. 173-183 (revisado para El síndrome..., 67-81), o con la extraña corrección política de una crítica reconocida (Josefina Ludmer) en "Aquí Argentina". Cuando el Nobel, entre otros homenajes de las nuevas generaciones, véase de Abad, 2010, p. 53; y de Vásquez, "El malentedido Vargas Llosa", 2010, p. 56. 
al cineasta de ese mismo país Peter Greenaway, empleando una frase cuyos avatares se encuentra en el resto del libro: "Nuestra realidad, parece decir Greenaway, no sólo puede ser una hipótesis narrativa sino que siempre lo es" (2008a: 157). En esta larga sección, el ensayo "El tiempo de los inasibles" analiza de manera deslumbrante y enterada el desarrollo desde 1950 hasta su momento de novelas hispanoamericanas indefinibles, y por ende conceptualizadas bajo diferentes e infinitamente ricas categorías. Este gran ensayo lo distingue de Abad, Fuguet y Volpi, y sobre todo del academicismo universitario apegado a la jerigonza excesiva.

La tercera y última sección de El síndrome de Falcón examina los grupos con los cuales ha sido identificado imperfectamente, y ésta es la más autocrítica de sí mismo como escritor, e implícitamente de la escritura de sus contemporáneos, de cuyos mundillos sociales no participa. Esta sección lo separa aun más del montón, y los cinco ensayos que incluye ilustran otra de sus coordenadas estéticas: la concisión. Estos ejes además se forman con una noción renovada del libro infinito, como sigue haciendo con el "ciclo de cuentos" La luna nómada, su punto de partida como narrador; y con el concepto del "libro flotante", puesto en práctica en sus novelas más recientes, El libro flotante de Caytran Dölphin (2006) y Kazbek (2008b). En una reseña conjunta de ésta y El síndrome de Falcón, Óscar Carreño se refiere a la última con razón como "ese intento de transgredir el acote a una tradición literaria nacional que prefigura temas, preocupaciones, apuestas estilísticas y hasta formas de tratamiento del lenguaje, o anquilosamiento en la visión que Valencia tiene del fenómeno" (2009: 74), porque el andamiaje conceptual de esa novela determina su acercamiento a los narradores que examina. Esta sección también sirve para atar otros cabos conceptuales con la noción del escritor como nómada, y la presunta imperfección de esas coordenadas las hace más vulnerables.

Su noción del nómada fue ensayada previamente en la nota "Esa tribu errante" de la primera sección, y al purgar posteriormente el acto de narrar de toda ostentación y sentimentalismo nos deja con un entendimiento renovado que emigrar es convertirse en extranjero en dos lugares a la vez. En "El tiempo de los inasibles", que también es un elogio al cosmopolitismo, se explaya acerca de la resistencia a las cartografías existentes de la narrativa hispanoamericana, actitud que resume con "Me refiero a la trasgresión de autores que exploran otros escenarios del mundo" (21). Aparte de proveer un extenso y novedoso registro de autores y obras que llega hasta el 2008 (27-29), para perfilar la "orilla internacionalizada" (26), la mejor expresión de su revisionismo es: “Toda especialización o segmentación en el territo-

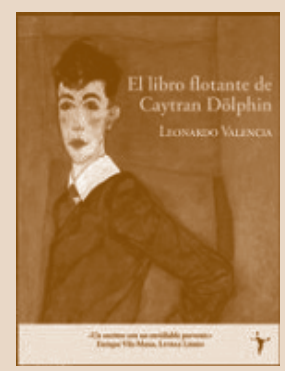


rio literario de Latinoamérica significa una resta que termina por llevar al desaliento de lo banal, a la cortedad de miras y, sobre todo, a la pérdida de una estatura intelectual y de escritura" (25). Sólo en Bolaño y Aira se puede encontrar similar valentía.

Más concentrado en la práctica personal y nacional, en "Nunca me fui con tu nombre por la tierra" (222-231), que contiene ecos y complementa al ensayo que le da título a la colección (167-190), afirma: "Y ya no es fácil escribir una novela sobre cualquier individuo de mi país porque también hay que integrar todo el fenómeno de la emigración y, ahora, el de las nuevas tecnologías" (223). "Esa tribu errante", que por su título parecería tener una mayor relación con "El tiempo de los inasibles", es una explicación razonada de una condición: "La teoría literaria contemporánea, los críticos y académicos, siguen fascinados por los procedimientos narrativos que hibridizan los géneros y multiplican las nociones que sostienen lo específico de cada narración, hemos llegado quizá a una exaltación de lo híbrido y a la banalización de lo híbrido" (17). Valencia arguye que mientras más se van acumulando las teorías, lo más que parecen agotarse, o convertirse en bosquejos aburridos. No hay que estar de acuerdo con su perspectiva para darse cuenta de que los excesos y estrategias teóricas de las últimas cuatro décadas han dificultado entenderlas, o hacer que importen.

Estos ensayos comprueban el trabajo de un gran prosista ya establecido, no "en obras", y de una madurez y sentido de certeza raros en estos momentos relativistas. Para todo el cohorte de Valencia la novela nunca se desprende de su protagonismo, y él no puede evitar depender de ella, o cuestionar, en los ensayos sobre Vila-Matas (94-100) y la gran mayoría de los incluidos en "Sobre la escritura" (la última sección), el ensimismamiento que sigue depurando en su propia práctica. Es claro que su valor como ensayista surge de un estilo refinado que emerge con facilidad dialógica desde los temas librescos más cercanos a él: los del siglo veinte tardío. También es patente que, como Abad, no escoge temas que no disfruta o en los cuales no encuentra diversión intelectual. Paralelamente, el no esforzarse por subrayar lo obvio y tener conciencia de la incompatibilidad de las memorias históricas lo distancia de Volpi, y lo acerca a Fuguet y Abad (ambos mayores que él), y sobre todo a autores de crónicas de viaje como Chatwin, Naipul, Morris, Theroux y otros contemporáneos. No es que a estos y a Valencia no les interesen los hechos, sino que prefieren captar la atmósfera, para luego transmitir lo que han vivido. $\mathrm{O}$ sea, es diferente del periodista que cree que intentar la objetividad en el periodismo lleva a una desinformación, y por eso se declara y compromete por algún lado en un conflicto. 
Argumento que, como sus coetáneos hispanoamericanos, Valencia se mueve con convicción y paulatinamente hacia una negociación entre crítica cultural y crítica literaria que no se concentra en detalles o lo previsiblemente formal. El síndrome de Falcón ya da indicios de ese gesto, y si se intuye algo en su periodismo no coleccionado, es que en cualquier momento va a dar otro giro. Se podría decir que la totalidad actual de su prosa no ficticia contribuye a una "autobiograficción" de la mente, pero no se podría decir que compone la narración de una vida. Lo que se tiene ante uno es sobre todo un intelectual y crítico que valoriza lo que la escuela de Frankfurt llamaba la "cultura política de la contradicción", aquella que se caracteriza por sus tensiones y divergencias culturales, desplegadas públicamente, y cuya finalidad es confrontar la opinión homogénea, para estimular más debates y discusiones, y, cuando posible, visiones más completas de las patologías que también definen al mundo literario. Valencia demuestra la capacidad de imaginar que la experiencia y necesidades de un otro-que casi todos los seres humanos poseen en alguna forma- tiene que ser enaltecida y refinada.

\section{VOLPI Y LA SERIEDAD QUE NO QUIERE SER CIRCUNSPECTA}

Con Volpi, la falta de calma de Fuguet, la chispa dialéctica de Abad y la reserva desafiante de Valencia se reemplaza con una búsqueda de autoridad que quiere depender de varios formalismos. En Mentiras contagiosas (2008), que no admite confusión con La verdad de las mentiras (1990/2002) de Vargas Llosa o Mentiras verdaderas (2001) de Sergio Ramírez, Volpi quiere basar su prolijidad en que sus lectores confirmen sus dictados, no en que los acepten. Entre los narradores de su país y pocos otros del continente, sigue siendo una figura potencialmente transformativa e importante. Sin embargo, en su corrección estilística y perspectiva intelectual formal se diferencia bastante de coetáneos prudentes como Valencia, y no mucho de su compatriota Padilla, articulista descuidado en sus intentos por chocar a los burgueses. En la interpretación literaria y sus "teorías" Volpi sigue siendo bastante convencional (para la novela, no pasa del respetable E.M. Forster y sus problemas con la modernidad), pretendiendo protegerse con un escudo que se mofa de la teoría, lo cual lo ubica en medio de la inmensa brecha que existe hoy entre un intelectual y el casi inexistente profesional del comentario cultural periodístico.

Paradójicamente, el pensamiento que ofrece en su ficción, donde alterna hermetismo semifilosófico con luminosidad narrativa, hasta la fecha se

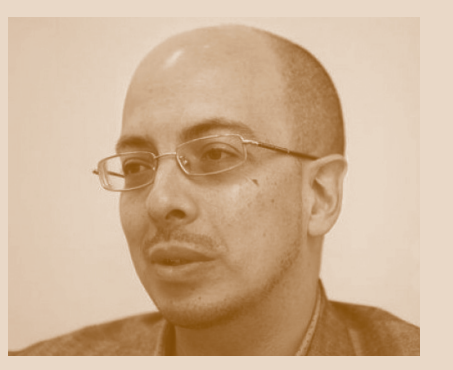

J. Volpi 
equipara fácilmente con el de los posmodernistas que su prosa no ficticia parece reprobar. En su magistral The Essayistic Spirit Claire De Obaldia aclara las similitudes y diferencias que hacen que ensayistas y novelistas en verdad sean tal para cual (184), advirtiendo que hay material ensayístico que no se ha disuelto en la tela de la novela (194), y sobre todo que desde las clásicas interpretaciones de Lukács sobre el ensayo, éste y la novela han sido "formas problemáticas de la escritura" (224). Es decir, ambos géneros son laboratorios de la comunicación literaria y de la imaginación sociológica. Por razones afines, la ficción de Volpi lleva una doble vida en la cual su maquinaria estilística y narrativa tradicional constantemente agobia la pretensión de presentar ideas sofisticadas.

Esta impresión se desprende de su invariable elección de autores mexicanos, y su constante mención de ellos como ejemplos a seguir. Empero a veces quiere separarse del terruño, porque no todos tenemos que pertenecer a algún lado. A la vez, aunque en principio no hay nada malo con el reciclaje, porque puede significar que se cree sinceramente en una idea, esta postura pierde su valor cuando se emplea el terruño como base, aun cambiándole el nombre al texto, no importa cuántos matices se le haya añadido. Así, el representativo ensayo "La obsesión latinoamericana" (143-154) de Mentiras contagiosas también se publicó en la Revista de la Universidad de México 31 (septiembre 2006), 90-92, en el dossier "A diez años del crack". Pero su proto-texto (hay otros publicados en actas académicas) salió primero como contribución a Palabra de América, esa demasiado selecta (y por ende poco representativa) muestra testimonial de los novicios, examinada en otro momento (Corral 2005).

El recurso de Volpi en las versiones de ese ensayo es citar in extenso un texto apócrifo, aunque certero en su tono apocalíptico, de "Lucius J. Berry, catedrático de Hispanic and Chicana Literature de la Universidad Estatal de Dakota del Norte". No deja de ser revelador que esa misma prosa fue recogida casi al mismo tiempo, sin ningún cambio o aviso, por la peruanoestadounidense Revista de crítica literaria latinoamericana, y que haya sido publicada como artículo académico, aparentemente sin que el consejo de redacción se diera cuenta del tono irónico de los comentarios de Volpi, o del aspecto apócrifo de las notas. No es casual la conjunción y confusión, y la prensa ha manifestado que el El insomnio de Bolivar (2009) "escapa al tono académico", como si hacerlo convirtiera la escritura del a veces académico Volpi más meritoria, o le diera un género que ese libro no tiene, como aseveran algunos comentaristas posteriores. Volpi sabe a quién se dirige, y piénsese en que en una colección académica de hace sólo dos décadas, 
Teoría de la crítica y el ensayo en Hispanoamérica, los ensayos dedicados a la crítica son de los setenta, como si entre esos años y los noventa no hubiera habido cambios generacionales o conceptuales importantes.

La dependencia en una crítica hispanoamericana sesgada hacia cierta tradición (anglosajona o hispanoamericana) no quiere decir que uno que otro ensayo no tenga vigencia. Por ejemplo, en 1973 Antonio Alatorre argüía que el crítico tiene que tener en mente el aspecto coyuntural de su quehacer, y se refiere a una "verdad eterna": "De esto se sigue que el crítico está aprendiendo siempre. No se hace de una vez por todas. El verdadero crítico habla desde su experiencia; y como es natural, la experiencia de las obras literarias (a semejanza de la experiencia de la vida) no tiene límite" (1990: 26, su énfasis). A su vez, Raúl Bueno Chávez enfatizaba la obvia necesidad de considerar con respeto "toda labor realizada por una crítica anterior, no sólo porque su metodología hermenéutica y los resultados de la aplicación de ésta resultan en alguna medida aportados a la nueva crítica, sino también por el hecho de que, en determinado momento, ella hace necesario y permite un nuevo estado de crítica" (1990: 73). Vale ponderar por qué, desde El ensayo y la crítica literaria en Iberoamérica (1970), actas de un congreso de 1969, el tema no merece una atención sostenida más allá de estudios individuales o compilaciones dedicadas estrictamente al ensayo, la historia de las ideas, o al pensamiento definido ampliamente como "crítico", en que la literatura brilla por su ausencia. Se deduce de esta ponderación que, diferente de la larga tradición hispanoamericana que permite a literatos y científicos sociales hablar distintamente de pensadores y ensayistas, los narradores actuales tienden a desatenderse de esos límites.

Volpi se aproxima a una contradicción generacional o autocrítica (por sus caprichos, como todo autor) al criticar el boom y sugerir asesinarlo "de modo natural y sin escándalos". Esto no es nuevo, y vale acordarse, como hizo Cortázar, que el argentino y sus coetáneos hicieron sus obras iniciales solos, y escribieron lejos de las editoriales, y entre éstas las europeas celebraron el primer boom sólo cuando se dieron cuenta de que sus autores vendieron bien sus primeras ediciones y se comenzaba a interesar el público anglosajón y francés. Vale recordar también, que en un libro publicado antes de que nacieran los narradores de entresiglo, Zum Felde, el gran crítico uruguayo hoy olvidado, aseveraba: "Dentro de los caracteres comunes, universales, de cada época de la cultura occidental, la histórico-crítica destaca perfectamente las diferencias de estilo nacionales" (1954: 21), así que Volpi habría tenido que pensar en los denominadores comunes que dan unidad literaria nacional y universal. 


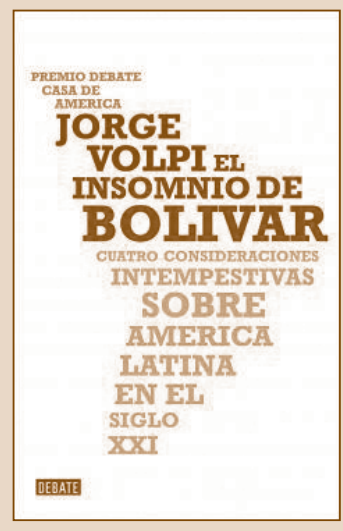

Desde ese contexto, cuando en El insomnio de Bolívar empotra un recuadro (uno de varios que desestructuran cualquier unidad que haya pretendido darle al libro) llamado "Adiós a los críticos" (2009: 191-192) revela más un pesimismo personalizado que una situación demasiado conocida que no necesita pontificaciones, sino una ponderación con nombres y apellidos y ejemplos concretos. Cuando identifica, lo hace por medio de un cuadro con categorías frívolas sobre la "Evolución del escritor latinoamericano (del Boom a nuestros días)" (163-164). Habría que aplicar algo del proverbio "Zapatero a tu zapato" a esta prosa, porque estemos de acuerdo o no con la extensa "Tercera consideración", dedicada a la nueva literatura hispanoamericana que lo define a él, también contiene una exhaustividad que, si no deja de tener comentarios gratuitos o vagos, tiene valor documental de primera mano.

Volpi apoya el deseo de una "literatura de calidad" porque no importa qué discuta en El insomnio de Bolivar, sobre todo respecto a la política, siempre se refugia en lo literario, a veces de manera autobiográfica (véase el prólogo "Confesión y difusión", 2009: 15-26), o en analogías débiles como "Si en la ficción literaria América Latina se identifica de modo unívoco con el realismo mágico, en política se halla indisolublemente ligada a su contraparte real: el libertador, el caudillo, el dictador, el déspota" (2009: 48-49). La complicación yace en la imprecisa división de labores discursiva. Para un reseñador de El insomnio de Bolivar: "El problema, casi sobra decirlo, no son las provocaciones, tremendas o desdentadas según la sensibilidad de quien las lea. El problema son las incoherencias: querer rescatar a América Latina del realismo mágico y, acto seguido, proclamar que la literatura latinoamericana ha dejado de existir" (Bravo Regidor, 2009: 77). Otro reseñador implícitamente defiende el "neoliberalismo" que presuntamente ataca Volpi, observando que "rehúsa participar del pensamiento utópico que ha seducido y corrompido a tantas mentes latinoamericanas" (Mejía Vergnaud, 2010: 116), y que "pierde la oportunidad de superar el estándar establecido por la mayoría de los intelectuales literarios latinoamericanos aficionados a las generalidades y poco dispuestos a indagar más" (2010: $117)^{6}$. Para ser justo con Volpi, no se puede esperar otra cosa de las reseñas en revistas progresistas o neoliberales en los Estados Unidos que erróneamente equiparan el fin del capitalismo de ese país con el "fin de Occidente".

${ }^{6}$ Respectivamente, Carlos Bravo Regidor, 2009, p. 77; y Andrés Mejía Vergnaud, 2010, pp. 116-117. 
Mejía Vergnaud exagera y se equivoca al expresar que Volpi ofrece una "descripción aburrida, larga y exhaustiva de tendencias literarias actuales [sic] en América Latina" (2010: 116), porque los mejores momentos de El insomnio de Bolivar ocurren cuando su autor discute la narrativa, no la identidad de los últimos cincuenta años (2009: 67-77); y sobre todo cuando se lee a sí mismo, no necesariamente para corregirse sino para constatar opiniones anteriores, como cuando asevera "En Mentiras contagiosas (2008), he comentado las posibles causas de la fascinación que Bolaño ejerce entre los escritores y lectores más jóvenes, pero allí me limitaba al campo hispanoamericano, mientras que la aparición de la edición inglesa [sic] de 2666 marca un nuevo hito en esta canonización ..." (2009: 172).

Si en las cuatro partes de El insomnio de Bolívar Volpi se ubica como testigo del pasado histórico inmediato, que conduce a los bicentenarios actuales y la relevancia del concepto "América Latina", las cinco secciones y subdivisiones asimétricas de Mentiras contagiosas lo presentan como testigo estrictamente literario. Mientras en "América Latina, holograma" (2009: 149-207), tercera parte de El insomnio de Bolivar, su obsesión con Bolaño "el último escritor latinoamericano" es patente, en la quinta sección de Mentiras contagiosas, "Nuestros antepasados" (2008: 155-251), su fascinación con los maestros, incluido Bolaño, es manifiesta, y reveladora de una toma de posición a medias, como no ocurre en las notas dedicadas a sus compatriotas, o acerca de la reciclada muerte de la novela (2008: 11-16, 2137). Hay en esta ensayística la sensación de que se compone de infundios sectarios que descalifican, de lecturas que son y deben ser tan libres como los géneros que discute, no como del novelista como oráculo, o del crítico que teme mencionar a personas específicas.

En una reciente defensa suya de la indispensabilidad de la novela, que se va por ramas cuasi-científicas, se refiere a un "novelista neoyorquino", critica la metaficción, y da nombres sólo cuando necesita apoyar sus argumentos. Asevera: "Los humanos somos rehenes de la ficción. Ni los más severos iconoclastas han logrado combatir nuestra debilidad y nuestra dependencia por las mentiras literarias" (2011: 52). Concluye exagerando que el género tiene una esencia práctica, después de reiterar que "nuestro cerebro siempre nos impulsa a colocarnos en el lugar de los personajes de un cuento o una novela" (2011: 54). Esa subjetividad sobre la legibilidad del mundo, a la cual tiene todo derecho, es pobre comparada con los argumentos de Abad sobre la moralidad en la novela. Según De Obaldia, la relación más radical entre unos textos no se da entre los estrictamente "literarios" sino entre las nociones que Occidente considera "ensayo", "literatura" y "crítica moderna"

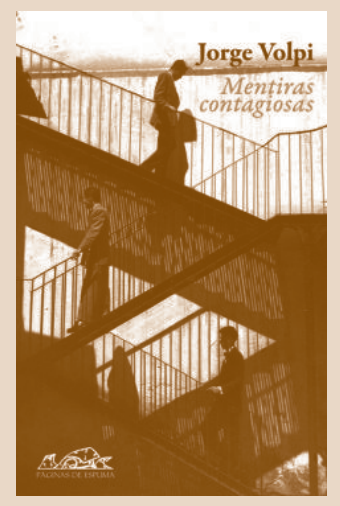


(1995: 55). Es decir, las interpretaciones inamovibles exponen el poder del ensayo para agobiar las emociones e influenciar varias perspectivas.

\section{¿DE DÓNDE SURGE LA REDEFINICIÓN?}

La redefinición proviene naturalmente de la idea que los autores tienen de la prosa. Los teóricos y críticos del siglo veinte trataron de definirla, pero no hay ninguna evidencia de que sus postulados hayan pasado al manual de los usuarios, o superado las luchas seculares sobre la prosa y otros géneros, y un recorrido somero muestra ciertas conexiones. Los formalistas Víktor Shklovski y Boris Tomashevski, siguiendo distinciones que veían en la prosa un empleo no artístico, se explayaron respectivamente sobre la correlación entre composición y estilo, más el ritmo que proviene de la estructura formal. Para estructuralistas y semióticos tardíos como Lotman y Bajtín, la prosa tiende a combinar, y sólo la novela puede presentar cabalmente la complejidad de imágenes dialógicas. Finalmente, en Idea della prosa, Agamben (1985) postula que una "prosa" nueva es un pensamiento que busca una forma nueva, y para establecer sus bases recurre a "formas simples" como el aforismo y la fábula, con el fin de comprobar que el problema del pensamiento es un problema poético que quiere hacer viva una experiencia. Tampoco es nueva esta perspectiva, y los nuevos narradores tienen razón en dejar a Agamben para los críticos profesionales, no para sus propias definiciones.

Mencionaba al principio que las nuevas narradoras brillan por su ausencia en este corpus de prosa no ficticia. Es cierto que autoras como Allende, Laura Esquivel (1950), Angeles Mastretta (1949), Laura Restrepo (1950) en sus crónicas no recogidas, Zoé Valdés (1959) y pocas otras tienen acceso a los medios masivos, que no tuvieron las contemporáneas del boom. Si es indiscutible que Una novelista en el Museo del Louvre (2009) de Valdés es un ensayo "novelizado", que su El ángel azul (2008a) es más un elogio cinematográfico que un análisis de un artista, o que su La ficción Fidel (2008b) es más un panfleto político, también es innegable que ellas y estas autoras no parecen interesadas en acceder a medios de menor exposición pero de mayor importancia para un público general culto, y habitualmente han optado por la literatura folletinesca y el trillado relato sentimental que vende. No es así, sin embargo, con otras narradoras de factura más reciente, como Rivera Garza, o la cubana Ena Lucía Portela (1972).

Las opiniones que se tiene de estos narradores revelan la persistencia de 
ciertos paradigmas coyunturales asociados a su época, junto a una falta casi natural de auto-especulación modesta, no exenta de reciclaje de parte de algunos de ellos. Ese auto-concepto está coadyuvado por un oximorónico entusiasmo cauteloso de sus escasos críticos especializados. Esa aclamación es secundada a veces por espaldarazos de los mismos autores, en entrevistas, libros, revistas y sondeos respecto a qué seguirá pasando con ellos, condiciones exacerbadas por notables prejuicios y una considerable falta de información o perspectiva al evaluarlos. Este proceder persiste, y se nota también en un apurado y poco informado dossier sobre "la nueva guardia" armado con referencias no obligadas por ADNCultura [2. 75 (17 de enero de 2009)], de La Nación bonaerense. De aquella selección sobresale sólo Castellanos Moya. Como arguye él en otro artículo publicado en el mismo suplemento, las percepciones tendrían que ver con cómo los nuevos narradores presentan su obra temáticamente y al mundo exterior, y yo añadiría con cómo perciben la política. Limitándose a la ficción de Bolaño, y en base a un artículo de una investigadora anglosajona, Castellanos Moya está de acuerdo con la visión de que "era muy difícil vender al lector estadounidense el mundo de los iPods y de las novelas de espías nazis como la nueva imagen de Latinoamérica y su literatura" (8). Es difícil negar alusiones a la ficción de narradores como Volpi y Paz Soldán en la cita de Castellanos Moya, o a cierta banalidad en la ensayística de ellos.

\section{CONCLUSIONES}

Por supuesto, no hay un progreso exactamente similar, una recepción parecida o un pensamiento compartido entre Abad, Fuguet, Valencia y Volpi. No obstante, los asemeja que a veces buscan el lado oscuro de aquella Neverland que puede ser la prosa/cultura actual, y es así porque ese híbrido nunca ha sido o puede ser visto como puro, valga el pleonasmo. Estos prosistas han heredado no tanto la actitud de ser anti-, sub- o seudo- algún maestro, sino una preferencia por una gran gama de lecturas e intereses culturales que, vaya ironía, algunos lectores por lo general no tienen. Con las salvedades discutidas, en una época relativista en que se celebra la conveniencia, la ciencia falsa y la seudo-historia, la simpleza y el éxito instantáneo, la fama y el ruido, la prosa examinada es un antídoto bastante completo contra ese estado cultural aparentemente definitorio. En su nomadismo temático, como compañeros de viaje ideales, informan y divierten, especulan y sobresaltan. También introducen detalles, a veces sobre sí mismos, y vuelven sobre sus 
pasos para enriquecerlos y envolverlos en una narración cada vez mayor.

Ese método sin método les sirve entonces para elogiar la dificultad, el fallo, la inteligencia, la oscuridad y el silencio discreto con menos rodeos. La esperanza de esta prosa no ficticia es conectar a sus lectores con algo que esté fuera de los libros, sea el pasado, un descubrimiento, un asunto social. Para lograrlo los nuevos narradores naturalmente necesitan recurrir a palabras e imágenes preexistentes, para redefinirlas. Como también se ha visto, cuando las fuentes reales son redefinidas se convierten en parte del fluir de una nueva narración cultural, que nunca se reduce al entretejer de ficción y realidad, sino que alienta a los narradores a emplear más arte, que es precisamente lo que quiere todo lector exhausto del fin de siglo inmediatamente pasado.

\section{REFERENCIAS}

Abad Faciolince, H. (1995). "Las hazañas de una impostura". Voces de Bohemia. Doce textimonios colombianos sobre una vida sin reglas (pp. 15-28). Ed. Hugo Sabogal. Bogotá: Norma. . (2007). Las formas de la pereza. Bogotá: Aguilar. . (2008a). "El olvido que purifica, la memoria que elige". El Búho VI.26 (julio-octubre), 44-50.

. (2008b). Oriente empieza en El Cairo. Bogotá: Alfaguara. . (2008c). "Estética y narcotráfico". Revista de Estudios Hispánicos 42(3), 513-518.

. (2009a). “Un poema en el bolsillo”. Letras Libres XI. 128 (agosto), 16-25. . (2009b). Traiciones de la memoria. Bogotá: Alfaguara. . (2010, octubre 8). "Fuego intelectual", El País, 53.

Agamben, G. (1985). Idea della prosa. Milano: Feltrinelli.

Aira, C. (2007). Pequeno manual de procedimentos. Org. Eduard Marquardt; Marco Maschio Chaga. Trad. Eduard Marquardt. Curitiba: Arte \& Letras.

Alatorre, A. (1990). “QQué es la crítica literaria?”. De Torre, G. (Ed.), Teoría de la crítica y el ensayo en Hispanoamérica (pp. 15-27). La Habana: Editorial Academia.

Bolaño, R. (2004). Entre paréntesis. Barcelona: Anagrama.

Booker, Ch. (2004). The Seven Basic Plots: Why We Tell Stories. London-New York: Continnum.

Bravo Regidor, C. (2009). “¿América Latina ya no es lo que era?”. Letras Libres [México] XI. 132, 77.

Carreño, Ó. (2009). "Ecos y espejo de la literatura ecuatoriana”. Quimera 311 (Octubre), 74-75.

Castellanos Moya, H. (2007). "Sobre el mito Bolaño." ADNCultura II.110 (19 de septiembre), 8-9. 
Corral, W. H. (2005). "Y tus padres también: testamento de los nuevos narradores hispanoamericanos". Cuadernos Hispanoamericanos 663 (septiembre), 89-97.

. (2009). “Qué queda del sesentayochismo en los nuevos narradores hispanoamericanos?". Guaraguao 13(30) (Verano), 39-54.

De Obaldia, C. (1995). The Essayistic Spirit: Literature, Modern Criticism and the Essay. Oxford: Clarendon Press.

De Torre, G. (1990). Teoría de la crítica y el ensayo en Hispanoamérica. La Habana: Editorial Academia.

Escobedo Prieto, M. (2010). "Héctor Abad: 'Nunca estoy seguro de si estoy rememorando o inventando"'. Cuadernos Hispanoamericanos 719 (mayo), 105-116.

Fuguet, A. (1998). Tinta roja. Santiago: Alfaguara. . (2000). Primera parte. Santiago: Aguilar Chilena de Ediciones. - (2007). Apuntes autistas. Santiago: Aguilar Chilena de Ediciones. . (2009). Missing (una investigación). Santiago: Alfaguara.

Fuguet, A. y Gómez, S. (1996). McOndo. Barcelona: Mondadori.

Goic, C. (2009). Brevísima relación de la historia de la novela hispanoamericana. Madrid: Biblioteca Nueva.

Mejía Vergnaud, A. (2010). "El insomnio de Bolivar”. Americas Quarterly 4.2 (Spring), 116-117.

Rioseco, M. (2010). "Latin America Also Has iPods: The Nonfiction Books of Alberto Fuguet”. World Literature Today 84(4) (July-August), 15-18.

Román, A. (2010). "Se los tragó Colombia”. Nexos XXXII. 396, 84.

Salmon, Ch. (2008). Storytelling. La máquina de fabricar historias y formatear las mentes, trad. Inés Bértolo. Barcelona: Península.

Valdés, Z. (2008a). El ángel azul. Barcelona: Gedisa. . (2008b). La ficción Fidel. Barcelona: Planeta.

- (2009). Una novelista en el Museo del Louvre. Barcelona: La otra orilla.

Valencia, L. (1998, marzo 14). "Respuestas a Vargas Llosa de 10 novelistas jóvenes de Hispanoamérica”. Lectura, El Nacional Nueva Época, 4-9.

. (2005). "Mario Vargas Llosa: el guardián ante el abismo". Cuadernos Hispanoamericanos 661-662 (julio-agosto), 173-183.

. (2006). El libro flotante de Caytran Dölphin. Madrid: Funambulista.

. (2008a). El síndrome de Falcón. Quito: Paradiso Editores.

. (2008b). Kazbek. Madrid: Funambulista.

. (2010). “Aquí Argentina”. Letras Libres XII.144 (diciembre), 93-94.

Vargas Llosa, M. (2010, febrero 7). "La amistad y los libros”. El País, p. 37.

. (2011, enero 2). “Carlos o el sueño americano”. El País, p. 5.

. (2011). Cartas a un joven novelista. Madrid: Alfaguara.

Vásquez, J. G. (2009). El arte de la distorsión (y otros ensayos). Bogotá: Alfaguara. . (2010, octubre 8). "El malentedido Vargas Llosa", El País, p. 56.

VVAA. (1999). Líneas aéreas. Edición y prólogo de Eduardo Becerra. Madrid: Lengua de Trapo. 
Volpi, J. (2008). Mentiras contagiosas: ensayos. Madrid: Páginas de Espuma. . (2009). El insomnio de Bolívar. Cuatro consideraciones intempestivas sobre América Latina en el siglo XXI. Madrid/México, D.F.: Debate. (2011). "Yo soy una novela". Nexos XXXIII. 399 (marzo), 50-54.

Volpi, J.; Urroz, E.; Padilla, I.; Chávez, R. y Palou, P. A. (2000 [1996]). “Manifiesto Crack". Lateral. Revista de Cultura No 70 octubre de 2000. http://www. lateral-ed.es/tema/070manifiestocrack.htm

Zum Felde, A. (1954). Índice crítico de la literatura hispanoamericana. El ensayo y la crítica. México D.F.: Guarania. 